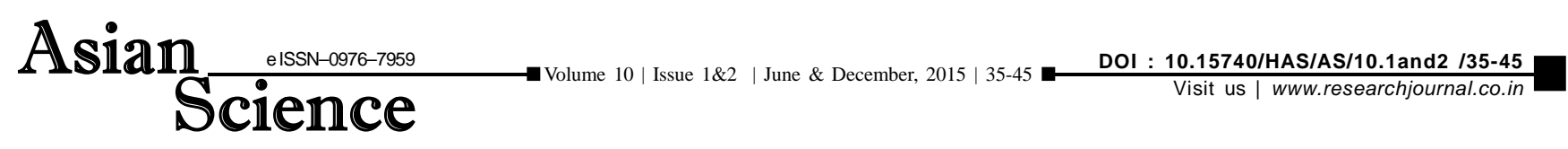

A CASE STUDY

\title{
The concept of justice
}

\author{
SHRIYA SINGH* AND HEMANGINI SHAH \\ Department of Law, New Law College, Bharati Vidyapeeth, PUNE (M.S.) INDIA
}

\section{Key Words : Concept, Justice}

View point paper : Singh, Shriya and Shah, Hemangini (2015). The concept of justice. Asian Sci., 10 (1\&2): 35-45.

$\mathrm{T}$ he term justice suggests the quality of being just or right or reasonable. It is opposed to what is unjust or wrong or unreasonable. The word just, right and reasonable are primarily moral attributes and hence, just is primarily a concept of morality.

As a moral concept, justice is a dynamic ideal. It is a dynamic idea because our realisation of the ideal is a continuous process.

The concept of 'justice' and to act justly is held as the fundamental aspiration of any legal system. Therefore, the concept of justice and its appeal is universal. The final goal of every legal system is to secure justice.

Man has been striving for maintenance of justice. In a democracy, justice is given the highest place. The word justice is derived from the latin word 'Jus' which means 'to bind', 'to contract'. The Greek word for Justice is 'Dike'. It gives the meaning of nearer to 'Righteousness'. Justice means following the norms. Justice stands for just conduct, fairness or exercise of authority in maintenance of right.

The concept of justice is as old as the political theory itself. There has been variety of views given to justice from time to time. some writers regarded justice as a 'virtue', while others hold it for equality for some it is a the rule of law. The standard of justice is not something bound within the criterion of law but a criterion according to which the operation of law amongst other social mechanisms might be judged.

\section{Meaning and concept of justice :}

Different political thickness have given different views on the definition of justice.

\section{Salmoud :}

Law may be defined as the body of principles recognized and applied by the state in the administration of justice (Das, 2012).

\section{Roscoe pound :}

Law is the body of principles recognised or enforced by public and regular tribunals in the administration of justice (Das, 2012).

\section{Digest :}

Justice is a fixed and abiding disposition to give to

\footnotetext{
* Author for correspondence

Shriya Singh, Department of Law, New Law College, Bharati Vidyapeeth, PUNE (M.S.) INDIA (Email: shriya.law@ gmail.com)
} 